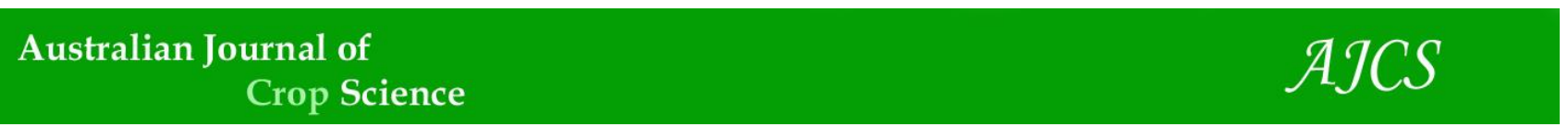

AJCS 14(12):2020-2027 (2020)

ISSN:1835-2707

doi: 10.21475/ajcs.20.14.12.2937.pdf

\title{
Application of the bacterial strains Ruminobacter amylophilus, Fibrobacter succinogenes and Enterococcus faecium for growth promotion in maize and soybean plants
}

\author{
Lívia de Paula Silveira Mello ${ }^{1}$, Ana Cláudia dos Santos ${ }^{1}$, Roberta Mendes dos Santos ${ }^{1}$, Saveetha \\ Kandasamy ${ }^{2}$, George Lazarovits ${ }^{2}$, Everlon Cid Rigobelo*1
}

${ }^{1}$ Graduate Program in Agricultural Microbiology, Faculty of Agrarian and Veterinary Sciences, State University of São Paulo (UNESP), Jaboticabal, Brazil

${ }^{2}$ A \& L Biologicals, Agroecological Research Service Center, London, ON, Canada

*Corresponding author: everlon.cid@unesp.br

\begin{abstract}
Ruminobacter amylophilus, Fibrobacter succinogenes and Enterococcus faecium have characteristics that are similar to those of plant growth-promoting bacteria and can be used to promote plant development and reduce production costs. These bacteria were isolated from fistulated ruminants and are gram-negative, anaerobic or facultative anaerobic. These bacteria are frequently used to increase animal productivity through the production of many enzymes responsible for the carbon cycle and the release of other nutrients by organic matter decomposition. The bacteria $R$. amylophilus, $F$. succinogenes and E. faecium have growth promotion abilities, such as phosphorus solubilization, nitrogen promotion, and indole acetic acid and siderophore production. Tests were performed under greenhouse conditions with soybean and maize crops with five treatments and six replications. The first treatment was the control (without inoculant); the other treatments included each species of bacteria, and there was a treatment with a mixture (mix) of the three bacteria. F. succinogenes increased the root dry mass of maize by $21.4 \%$, as well as the nitrogen and phosphorus contents, compared to the control. R. amylophilus and E. faecium decreased the phosphorus concentration in shoots of maize, and $R$. amylophilus increased the soil biomass carbon by $76.39 \%$ compared to the mix under maize cultivation, while E. faecium decreased the soil biomass carbon by $56.78 \%$ compared to the mix under soybean cultivation. The present study verified that Ruminobacter amylophilus, Fibrobacter succinogenes and Enterococcus faecium presented plant growth-related abilities and could be used to improve plant development, reducing the necessity of chemical fertilizers.
\end{abstract}

Keywords: Agriculture; Plant Growth-Promoting Bacteria; Bioinoculants; Probiotics; Rumen.

Abbreviations: SDM: shoot dry mass; RDM: root dry mass; PGPR: plant growth-promoting rhizobacteria; PGPB: plant growthpromoting bacteria; IAA: indole acetic acid.

\section{Introduction}

The introduction of microorganisms as biological inoculants has proven to be one of the most efficient technologies for complementing and reducing the use of chemical fertilizers (Ramakrishna et al., 2019). Plant growth-promoting bacteria (PGPB) directly affect plant metabolism, providing nutrients that are generally scarce. These bacteria can fix nitrogen, solubilize phosphorus and produce plant hormones. In addition, they improve plant tolerance to stresses, such as drought, high salinity, and metal toxicity as well as phytotoxicity caused by insecticide application (Matthews et al., 2019).

There are many mechanisms by which bacteria can promote plant growth, such as indole acetic acid (IAA) production, whose main effect is the promotion of root and shoot development (Ye et al., 2019). As a consequence of IAA production, the plant becomes more efficient in taking up nutrients and water, promoting its development. Some bacteria can fix nitrogen from the atmosphere and make it available to plants. This bacterial ability is important due to the amount of nitrogen required by plants to grow and increase their yield (Ke et al., 2019). Another important characteristic of some bacteria in promoting plant growth is their ability to solubilize phosphorus. Although soil has phosphorus reserves, most of it is insoluble and not assimilable by plants, which limits plant growth; some bacteria can make phosphorus available to plants (Schmidt and Gaudin, 2018)

Iron is an important metal required by many bacteria as a cofactor for their growth and establishment in soil. Bacterial establishment is required for plant-bacteria interactions. However, iron is scarce in soils. Some bacteria can synthesize compounds with low molecular weights called siderophores. Siderophores allow these bacteria to uptake iron from soil more efficiently, ensuring their establishment in soil and eliminating some phytopathogens through competition for iron (Melo et al., 2016).

Some bacteria, such as Ruminobacter amylophilus, Fibrobacter succinogenes and Enterococcus faecium, are 
probiotic bacteria of the ruminal tract. Ruminants depend on the symbiosis between the host and the rumen microbiota for the uptake of nutrients from feed (Anderson, 1995; Pinloche et al., 2013).

$R$. amylophilus is a gram-negative, anaerobic bacterium that was isolated and described by Hamlin and Hungate (1956). $R$. amylophilus ferments nonstructural carbohydrates (starch, pectin, sugars), uses both ammonia as peptides and amino acids as a source of $\mathrm{N}$ and can produce ammonia (Russell et al., 1992). Hungate also isolated rumen bacteria $F$. succinogenes in 1950 for the first time (Hungate 1950). It is also gram-negative and anaerobic and plays a key role in the rumen (Bera-Maillet et al., 2004). It is a structural carbohydrate-fermenting bacterium, such as cellulose (Oliveira et al., 2007). The bacterium E. faecium is a grampositive bacterium that makes up part of the commensal microbiota of the intestines of humans and animals. They are anaerobic optional and ferment glucose and other carbohydrates, obtaining lactic acid as the final product (Carvalho, 2010). E. faecium specifically has a phenotype prominence of tolerance to nutritional stress, pointing to adaptations specific to this species that help explain its environmental persistence (Gao et al., 2018).

Although these bacteria have been classified as ruminal probiotics, they also show important abilities related to plant growth promotion, such as IAA production, nitrogen fixation, phosphorus solubilization and siderophore production. The hypothesis of this study is that these bacteria could have a plant growth-promoting effect due to these abilities. Therefore, these bacteria were inoculated into maize and soybean crops.

\section{Results}

\section{Bacterial isolates and the ability to promote plant growth}

The three isolates tested could produce IAA, solubilize phosphorus and fix nitrogen (Table 1), with the contents quantified and values calculated according to the standard curve in a previously described methodology.

Bacteria can solubilize phosphorus under in vitro conditions. $F$. succinogenes solubilized the highest amount of phosphorus, followed by R. amylophilus and E. faecium. The bacterial isolates were also able to fix nitrogen. The isolate that fixed the most nitrogen under in vitro conditions was $R$. amylophilus, followed by $F$. succinogenes and E. faecium. All three isolates showed the presence of siderophores; the coloration of the culture medium turned from blue to red/orange through the CAS assay (Fig. 1).

\section{Growth promotion in maize under greenhouse conditions}

The height of maize plants varied from 55 to $65 \mathrm{~cm}$, and the treatments presented similar heights compared to that of the control, with no significant differences according to the 5\% Duncan test. Additionally, the treatments presented similar dry shoot mass values among plants, showing no significant differences (Fig. 2A).

Treatments containing the $F$. succinogenes isolate showed a higher root dry matter (RDM) value in maize plants, significantly differing from that in the control (Fig. 2B). Regarding the nitrogen concentration in shoots, $R$. amylophilus and $E$. faecium bacteria decreased the concentration compared to that in the control (Fig. 3A), and the $F$. succinogenes treatments showed higher nitrogen concentration in the roots compared with that in the control (Fig. 3B). For the phosphorus concentration, there was no difference for shoots, and for the roots, F. succinogenes showed a high nitrogen content compared with that in the control (Fig. 3 C and D). R. amylophilus produced the highest microbial biomass carbon; however, there was no significant difference compared to that in the control treatment (Fig. $4 A)$. Additionally, there was no significant difference in the total soil bacterial count among the treatments (Fig. 4B).

\section{Growth promotion in soybean under greenhouse conditions condition}

R. amylophilus bacteria produced a significant increase in the height of soybean plants compared to that of the control treatment (Fig. 5), and there were no significant differences in average shoot dry matter (SDM) (Fig. 6A). However, the treatment that received the mix showed the highest root dry matter (RDM) compared with that of the other treatments in soybean plants (Fig. 6B). Nitrogen concentrations in the shoots and roots of soybean plants that received bacterial inoculations did not differ significantly from those of the control treatment (Fig. 7A and B). E. faecium and the bacterial mix significantly decreased the phosphorus concentration in shoots compared to that in the control treatment (Fig. 7C).

The bacterial mix promoted a significant increase in soil microbial biomass carbon compared to that in the control treatments under soybean cultivation (Fig. 8A). However, there was no significant difference in the number of total soil bacteria among treatments that received bacterial inoculations compared to that in the control treatment under soybean cultivation (Fig. 8B).

\section{Discussion}

As seen in plant growth-promoting rhizobacteria (PGPR), the presence of certain functions, such as indole acetic acid production, biological nitrogen fixation, phosphorus solubilization and siderophore production, are important and can promote plant development (Melo et al., 2016).

The bacterial isolates used in the present study are ruminal probiotic bacteria that, when present in adequate amounts, promote these benefits in the host. They play an important role in providing energy and nutrients to ruminants through the breakdown of macromolecules in animal feed (Lerner et al., 2019).

Ruminobacter amylophilus, F. succinogenes and E. faecium bacteria demonstrated important abilities related to plant growth promotion, such as the synthesis of phytohormone indole acetic acid (IAA). $R$. amylophilus produced the most IAA of the studied isolates, $9.69 \mu \mathrm{g}$ IAA $\mathrm{mL}^{-1}$, followed by $F$. succinogenes, $9.20 \mu \mathrm{g} \mathrm{IAA} \mathrm{mL} \mathrm{L}^{-1}$, and E. faecium, $7.60 \mu \mathrm{g} \mathrm{IAA}$ $\mathrm{mL}^{-1}$ (Table 1).

Phytohormones are organic substances that can promote, inhibit or modify the development of plants at low concentrations (Damam et al., 2016). Phytohormones promote the proliferation of root cells by overproduction of lateral cells and root hairs together with increased absorption of nutrients and water (Sureshbabu et al., 2016). Fibrobacter succinogenes promoted an increase in root dry matter in maize plants (Fig. 1B); however, there was no difference in dry matter from that of the control treatment in soybean plants (Fig. 5B). There was no difference in IAA production between $F$. succinogenes and $R$. amylophilus, and 
Table 1. Amount of IAA production, phosphorus solubilization and nitrogen fixation performed by isolates.

\begin{tabular}{lccc}
\hline Isolates & $\mu \mathrm{g}$ of IAA mL${ }^{-1}$ & $\mathrm{mg}$ of $\mathrm{P} \mathrm{mL}^{-1}$ & $\mathrm{mg}$ of $\mathrm{mL}^{-1}$ \\
\hline R. amylophilus & 9.69 & 7.37 & 12.34 \\
F. succinogenes & 9.20 & 9.31 & 11.23 \\
E. faecium & 7.60 & 2.53 & 10.34 \\
\hline
\end{tabular}

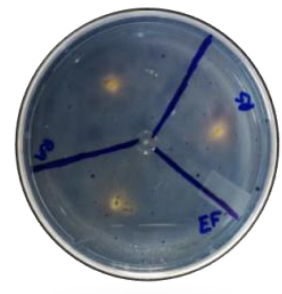

Control

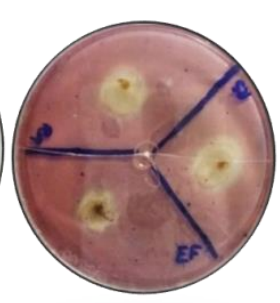

Siderophore +

Fig 1. Fibrobacter succinogenes in vitro test showing the presence of siderophores. The coloration of the culture medium turned from blue to red/orange through the CAS assay.

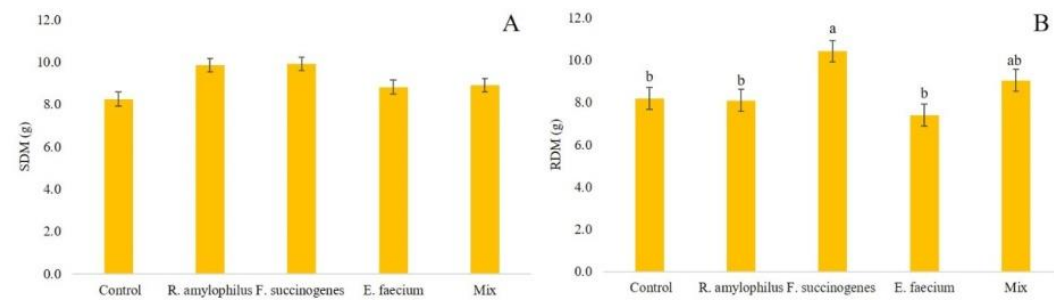

Fig 2. Shoot dry mass (SDM) (A) and root dry mass (RDM) (B) compared among treatments for the maize crop. Means followed by equal letters do not differ by Duncan's test at $5 \%$ probability. When there was no significant difference between the treatments, no letter was added.

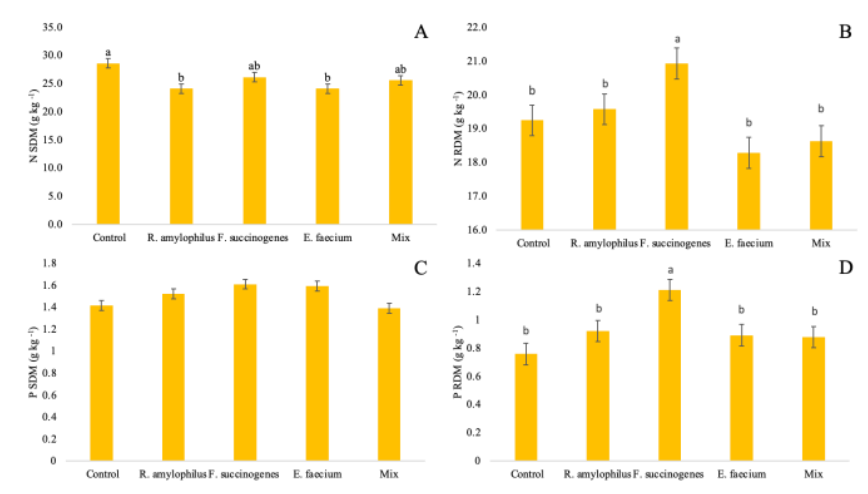

Fig 3. Nitrogen concentration in shoots (A) and roots (B) and phosphorus concentration in shoots (C) and roots (D) in the maize crop. Means followed by equal letters do not differ by Duncan's test at $5 \%$ probability. When there was no significant difference between the treatments, no letter was added.
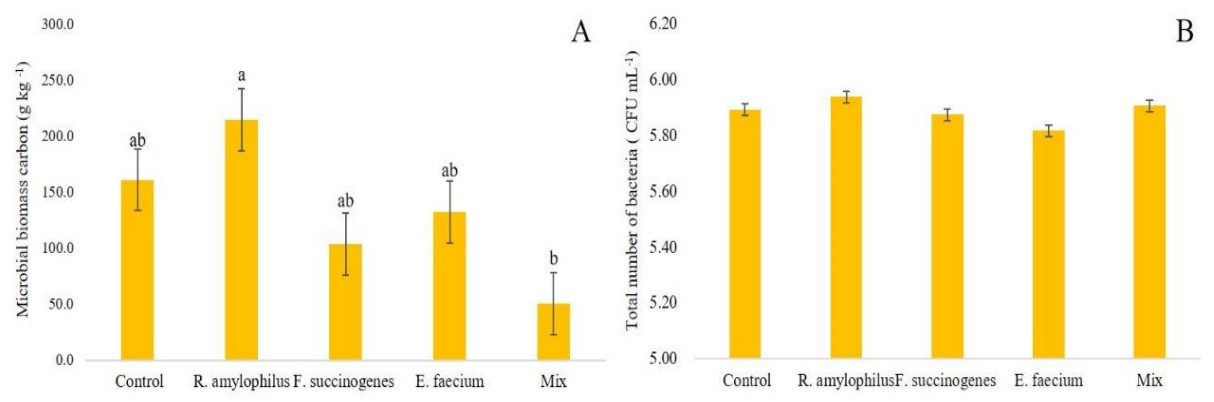

Fig 4. Analysis of (A) biomass carbon and (B) number of colony-forming units (data transformed into log 10) compared among treatments for the maize crop. Means followed by equal letters do not differ by Duncan's test at $5 \%$ probability. When there was no significant difference between the treatments, no letter was added. 


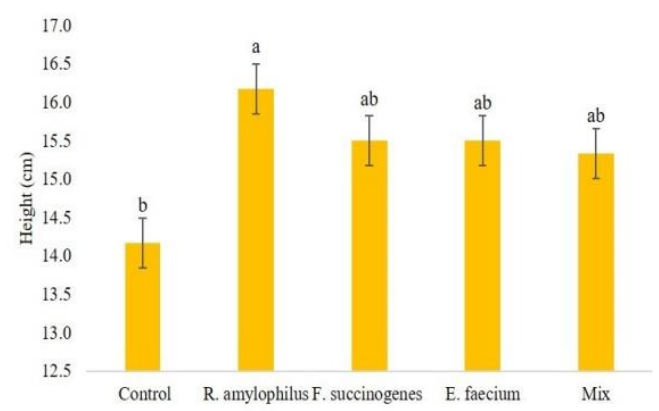

Fig 5. Plant height compared among treatments in the soybean crop. Means followed by equal letters do not differ by Duncan's test at $5 \%$ probability. When there was no significant difference between the treatments, no letter was added.
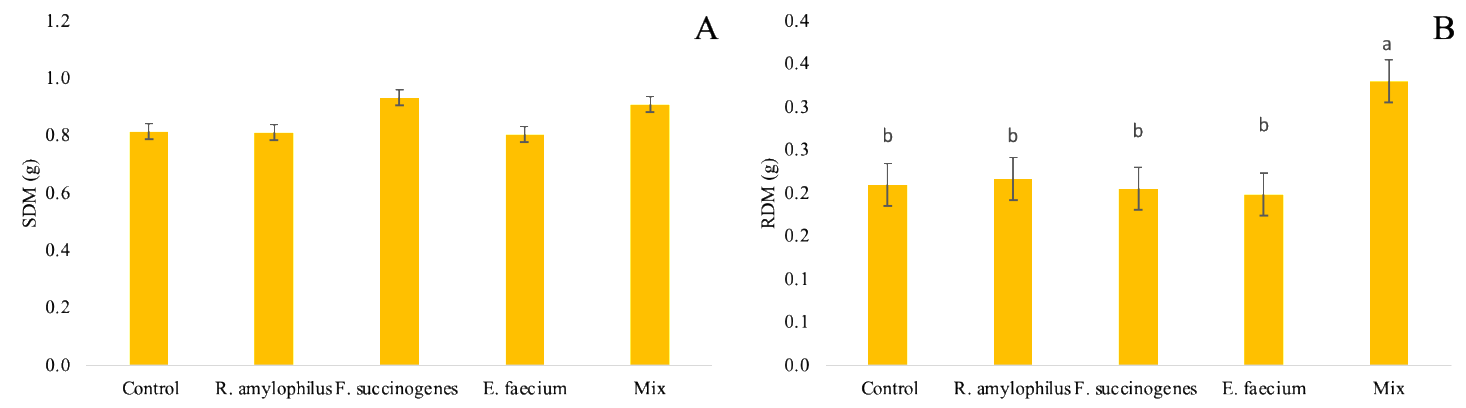

Fig 6. Average shoot dry mass (SDM) (A) and root dry mass (RDM) (B) compared among treatments in soybean crops. Means followed by equal letters do not differ by Duncan's test at $5 \%$ probability. When there was no significant difference between the treatments, no letter was added.
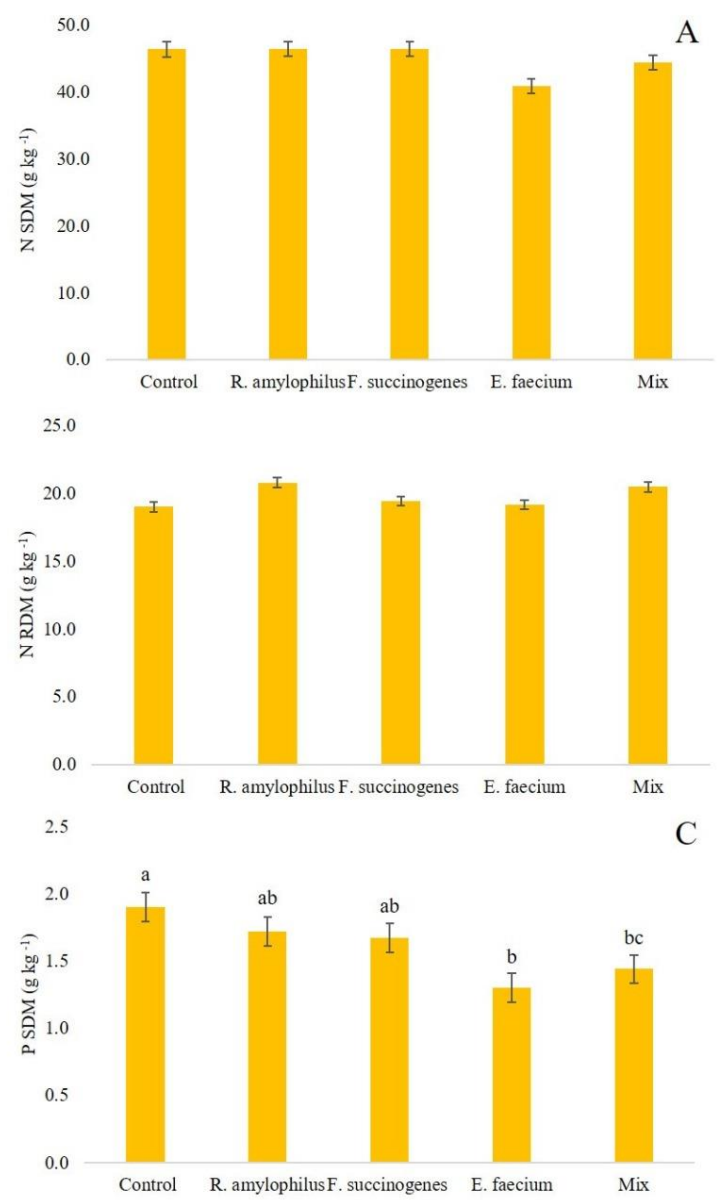

Fig 7. Average nitrogen concentrations in shoots $(A)$ and roots $(B)$ and average phosphorus concentrations in shoots (C) in the soybean crop. Means followed by equal letters do not differ by Duncan's test at $5 \%$ probability. When there was no significant difference between the treatments, no letter was added. 

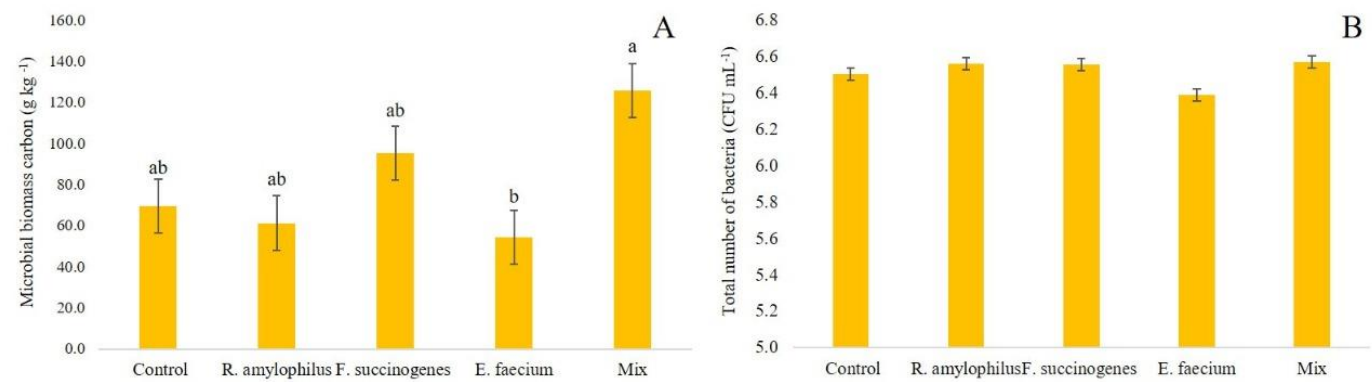

Fig 8. Analyses of (A) biomass carbon and (B) number of colony-forming units (data transformed into log 10) compared among treatments in the soybean crop. Means followed by equal letters do not differ by Duncan's test at $5 \%$ probability. When there was no significant difference between the treatments, no letter was added.

the increase in RDM caused by $F$. succinogenes in maize plants but not in soybean plants may be due to the greater interaction of the bacteria with the plant species. The first step for the colonization of bacteria in the rhizosphere and the subsequent interaction between bacteria and plants is the attraction of the bacteria by plant exudates. It appears likely that attraction to the root constitutes the first step toward the attraction of various plant growth-promoting bacteria toward whole-root exudates (Tan et al., 2013). Root exudates are a complex blend of high and low molecular weight compounds, many of which can induce chemotactic responses in PGPR (Bais et al., 2008). Molecules, such as small sugars, amino acids, aromatic compounds and small organic acids, have been suggested to be important drivers of bacterial attraction in the rhizosphere (Oku et al., 2012).

The exact composition of exudates in the rhizosphere varies significantly among plants, which allows for the specific recruitment of a cognate PGPR and their subsequent colonization of the root (Oku et al., 2012). This fact may be why $F$. succinogenes promoted an increase in root dry matter in maize plants but not in soybean plants.

Only F. succinogenes could increase the phosphorus concentration in plants. Talboys et al. (2014) reported a decrease in phosphorus concentration when wheat plants were inoculated with $B$. amyloliquefaciens. This negative effect may be due to the production of auxins by bacteria under certain soil fertility conditions, especially in soil with low phosphorus availability. Santos et al. (2018) also observed a reduction in soil $\mathrm{P}$ levels in sugarcane when inoculated with Bacillus subtilis and $B$. pumilus and attributed this effect to the high IAA concentrations synthesized by Bacillus. Interestingly, in these studies, phosphorus reduction occurred in roots, but in the present study, it occurred in shoots, and E. faecium did not produce the largest amount of IAA of the three bacteria in the study. Given these results, further studies are needed to verify the effect of $E$. faecium inoculation on soybean plants and to elucidate its modes of action.

The three bacterial isolates were also able to fix nitrogen, and the isolate that presented the highest nitrogen fixation value in vitro conditions was $R$. amylophilus, $12.34 \mathrm{mg} \mathrm{N} \mathrm{mL}^{-}$ 1 , followed by $F$. succinogenes, $11.23 \mathrm{mg} \mathrm{N} \mathrm{mL}^{-1}$, and $E$. faecium, $10.34 \mathrm{mg} \mathrm{N} \mathrm{mL}^{-1}$. Dynarski et al. (2019) showed that PGPR can increase $\mathrm{N}$ concentrations by 20 to $30 \%$ in grasses. In this study, it was not possible to verify which of the inoculated isolates had the best result for $\mathrm{N}$ accumulation in shoots and roots. An unexpected result was the reduction in the nitrogen concentration levels in the shoots of maize plants with $R$. amylophilus and $E$. faecium bacteria when compared to that in the control treatment.

The bacterial mix increased the biomass carbon in soil under soybean cultivation. This result shows that microbial establishment occurred in soil. Microbial establishment in soil is the first step toward PGPR and has a positive effect on plant development. However, the total soil bacterial count did not increase. This result suggests that a population rearrangement may have occurred, where the populations of certain microbial species may have increased and others decreased without changing the total number of microorganisms.

\section{Materials and Methods}

\section{Bacterial strains and growth conditions}

The isolates of $R$. amylophilus, $F$. succinogenes and $E$. faecium came from the collection of the laboratory of soil microbiology of the Universidade Estadual Paulista, Jaboticabal campus. All strains were isolated from cow rumen according to Hungate (1950) from the UNESP Farm (Avila et al., 1986; Rigobelo et al., 2016). The strains were identified by automatic sequencing of the $16 \mathrm{~S}$ ribosomal gene and stored in freeze-dried brain heart infusion (BHI) medium in a freezer at $-20{ }^{\circ} \mathrm{C}$. The strains were reconstituted by adding $25 \mathrm{~mL}$ of BHI medium to $2 \mathrm{~g}$ of each strain. The strains were kept in a microbiological incubator for $24 \mathrm{~h}$ at $38{ }^{\circ} \mathrm{C}$ for $48 \mathrm{~h}$ and 150 rotations per minute before use in subsequent assays.

\section{Bacterial plant growth promotion traits}

\section{IAA production}

Indole acetic acid (IAA) production was measured by the methodology of Kuss et al. (2007), and Ali and Hasnain (2007) qualitatively determined by the reddish coloration of the solution contained in vitro. For the quantitative evaluation of the hormone, the reading was performed in a spectrophotometer at a wavelength of $530 \mathrm{~nm}$.

\section{Detection of Siderophores}

CAS medium was prepared according to Schwyn and Neilands (1987), although only as a means to reveal changes 
rather than the presence of nutrients. All experiments were performed at least three times with three replicates for each experiment.

\section{Chemical determination of produced siderophores}

Chemical assays were performed to test the results obtained with the O-CAS method as follows: for hydroxamate detection, the $\mathrm{FeCl}_{3}$ assay (Neilands, 1981) was used. To detect catechols, the Arnow assay (Arnow, 1937) was used, and to detect carboxylates, the Shenker assay (Shenker et al., 1992) was used. Quantification was performed using a Lambda 35 spectrometer (Perkin-Elmer Instruments). All assays were performed at least three times with two replicates for each assay.

\section{Phosphorus solubilization in vitro}

The in vitro activity of fluorapatite solubilization was determined by transferring $0.2 \mathrm{~mL}$ of the $1 \times 10^{7} \mathrm{CFU} \mathrm{mL}-1$ suspension to an Erlenmeyer flask containing the medium described by Nahas et al. (1994) supplemented with $5 \mathrm{~g} \mathrm{~L}^{-1}$ fluorapatite (Araxá apatite). After inoculation, the bacterial solution was incubated with stirring at $28^{\circ} \mathrm{C}$ for two days at $20 \mathrm{rpm}$ on an orbital shaker. The control was an Erlenmeyer flask containing the same medium without bacterial inoculum. After the incubation period, the bacterial solution was removed and centrifuged at 9,000 rpm for 15 minutes, the supernatant was collected, and the amount of phosphate was determined according to Ames (1966).

\section{Nitrogen fixation in vitro}

Total nitrogen was determined according to the method proposed by Bremner and Mulvaney (1982). For each evaluation, a blank was made. The total nitrogen content was calculated based on a standard curve determined with ammonium sulfate solution.

\section{Plant growth promotion assay}

The experimental design was randomized blocks, with five treatments and six replicates, totaling thirty pots per crop. The experiment was performed in a greenhouse. The treatments were as follows: T1: control (without inoculant); T2: $R$. amylophilus; T3: F. succinogenes; T4: E. faecium; T5: mixture of the three bacteria (mix) with six repetitions.

Three seeds were planted in pots (vases) filled with five liters of soil. After one week, thinning was performed, and only one plant per pot was kept.

One week after sowing, each plot received $10 \mathrm{ml}$ of bacterial inoculum at a concentration of $1 \times 10^{8}$ colony-forming units through aerial parts with the aid of a pipette. The plants received three inoculations weekly throughout the experiment for 60 days, when the harvesting was performed manually.

The experiments were performed with maize genotype 2B587PW and soybean genotype 95R95IPRO.

\section{Height and dry mass}

Plant height was measured using a measuring tape from the base of the plant to the apex on the last day of experiments. Plants were collected, and the roots were washed in running water to remove excess soil. Shoots were separated from roots, and both were oven dried under forced air circulation at $65^{\circ} \mathrm{C}$ for approximately 72 hours until reaching constant weight to determine the dry matter content using an analytical scale.

\section{Phosphorus and nitrogen contents}

After weighing, the plant material was ground in a Wiley mill (mesh 20) and submitted to analysis of phosphorus and total nitrogen in leaves, according to the methodology described by Sarruge and Haag (1974). The nitrogen content was determined by the Kjeldahl method. Sulfuric digestion was used to obtain the extract, and nitrogen determination was performed by distillation in a Kjeldahl semimicro apparatus and titration with $0.02 \mathrm{~mol} \mathrm{~L}^{-1}$ sulfuric acid. Soluble phosphorus levels were measured as previously described for quantification of solubilization in vitro.

\section{Soil assessments}

\section{Counting of soil microorganisms}

The methodology of serial dilution from $10^{-1}$ to $10^{-3}$ according to Wollum (1982) was used. Then, $0.1 \mathrm{~mL}$ of each dilution was transferred to a Petri dish containing tryptic soy agar (TSA) culture medium and incubated in BOD at $25^{\circ} \mathrm{C}$ to $30^{\circ} \mathrm{C}$, allowing colony growth. Counts were performed at 24 , 48 and $72 \mathrm{~h}$ (Schortemeyer et al., 1996).

\section{Microbial biomass carbon}

To determine soil microbial biomass (SMB), the adapted (Islam and Weil, 1998) method was used. For extraction, 10 $\mathrm{g}$ of the soil sample was weighed into two $250 \mathrm{ml}$ Erlenmeyer flasks, with one identified as irradiated and the other as not irradiated. Irradiated soils were subjected to 15 seconds in a microwave 900 Watts per hour in each flask. Forty milliliters of $0.5 \mathrm{M} \mathrm{K}_{2} \mathrm{SO}_{4}$ was added to the Erlenmeyer flasks (irradiated and not irradiated), and the flasks were placed on a horizontal shaker for 30 minutes. The flasks were allowed to stand for another 30 minutes after stirring. Filtration was performed with funnel and qualitative filter paper, and the filtrate (extract) was collected in $50 \mathrm{ml}$ Erlenmeyer flasks.

For determination, $10 \mathrm{~mL}$ of each filtered extract was pipetted and transferred to a $125 \mathrm{~mL}$ Erlenmeyer flask containing $2 \mathrm{~mL}$ of $0.066 \mathrm{M} \mathrm{K}{ }_{2} \mathrm{Cr}_{2} \mathrm{O}_{7}$ and $10 \mathrm{~mL}$ of concentrated sulfuric acid. After lowering the temperature, $50 \mathrm{~mL}$ of distilled water and 4 drops of the ferroin indicator were added. Titration was performed with $0.03 \mathrm{M}$ ammoniacal ferrous sulfate.

\section{Statistical analysis of data}

Statistical analyses were performed using AgroEstat software (Barbosa and Maldonado, 2010). Normality and homogeneity of variances were tested by the Shapiro and Wilk (1965) test $(\alpha \leq 0.05)$. Differences were considered significant at $\alpha \leq 0.05$.

\section{Conclusion}

Ruminal probiotic bacteria present some plant growthrelated abilities and can be used to improve plant 
development and reduce the necessity of chemical fertilizers.

\section{Acknowledgments}

This work was performed with support from the Coordination of Improvement of Higher Education Personnel - Brazil (CAPES) - Financing Code 001.

\section{Compliance with ethical standards}

\section{Conflict of Interest}

On behalf of all of the authors, the corresponding author states that there are no conflicts of interest.

\section{References}

Ali B, Hasnain S (2007) Efficacy of bacterial auxin on in vitro growth of Brassica oleracea L. World J Microbiol Biotechnol. 23:779-784.

Ames B (1966) Assay of inorganic phosphate, total phosphate and phosphatases, vol. 8. Methods Enzym Ed by Neufeld, EF, Ginsburg, V, Acad Press.

Anderson KL (1995) Biochemical-analysis of starch degradation by Ruminobacter-amylophilus-70. Appl Environ Microbiol. 61:1488-1491.

Arnow LE (1937) Colorimetric determination of the components of 3, 4-dihydroxyphenylalanine-tyrosine mixtures. J biol Chem. 118:531-537.

Avila FA, Schocken-Iturrino RP, Ávila SHP, Quintana JL (1986) Evaluation of the immunizing efficiency of a pili k99bearing vaccine for the protection of cattle against Colibacillosis. Ars Vet. 2:217-220.

Bais HP, Broeckling CD, Vivanco JM (2008) Root exudates modulate plant-microbe interactions in the rhizosphere. In: Secondary metabolites in soil ecology. Springer, pp 241-252.

Barbosa JC, Maldonado JW (2010) AgroEstat: sistema para análises estatísticas de ensaios agronômicos. Versão 1.0.

Bera-Maillet C, Ribot Y, Forano E (2004) Fiber-degrading systems of different strains of the genus Fibrobacter. Appl Environ Microbiol. 70:2172-2179.

Bremner JM, Mulvaney CS (1982) Nitrogen-total 1. Methods soil Anal Part 2 Chem Microbiol Prop 595-624.

Carvalho IT (2010) Microbiologia de alimento. EDUFRPE.

Damam M, Kaloori K, Gaddam B, Kausar R (2016) Plant growth promoting substances (phytohormones) produced by rhizobacterial strains isolated from the rhizosphere of medicinal plants. Int J Pharm Sci Rev Res. 37:130-136.

Dynarski KA, Morford SL, Mitchell SA, Houlton BZ (2019) Bedrock nitrogen weathering stimulates biological nitrogen fixation. Ecology. 100:10.

Gao W, Howden BP, Stinear TP (2018) Evolution of virulence in Enterococcus faecium, a hospital-adapted opportunistic pathogen. Curr Opin Microbiol. 41:76-82.

Hamlin LJ, Hungate RE (1956) culture and physiology of a starch-digesting Bacterium (Bacteroides-amylophilus N-SP) from the bovine rumen. J Bacteriol. 72:548-554.

Hungate RE (1950) The anaerobic mesophilic cellulolytic bacteria. Bacteriol Ver. 14:1.

Islam KR, Weil RR (1998) A rapid microwave digestion method for colorimetric measurement of soil organic carbon. Commun Soil Sci Plant Anal. 29:2269-2284.
Ke XB, Feng S, Wang J, et al (2019) Effect of inoculation with nitrogen-fixing bacterium Pseudomonas stutzeri A1501 on maize plant growth and the microbiome indigenous to the rhizosphere. Syst Appl Microbiol. 42:248-260.

Kuss AV, Kuss VV, Lovato T, Flôres ML (2007) Fixação de nitrogênio e produção de ácido indolacético in vitro por bactérias diazotróficas endofíticas. Pesqui Agropecu Bras. 42:1459-1465.

Lerner A, Shoenfeld Y, Matthias T (2019) Probiotics: If it does not help it does not do any harm. Really? Microorganisms. 7:20.

Matthews A, Pierce S, Hipperson H, Raymond B (2019) Rhizobacterial community assembly patterns vary between crop species. Front Microbiol. 10:13.

Melo J, Carolino M, Carvalho L, et al (2016) Crop management as a driving force of plant growth promoting rhizobacteria physiology. Springerplus. 5:1574.

Nahas E, Centurion JF, Assis LC (1994) Microrganismos solubilizadores de fosfato e produtores de fosfatases de vários solos. Soc Bras Ciência do Solo. 18:43-48.

Neilands JB (1981) Microbial iron compounds. Annu Rev Biochem. 50:715-731.

Oku S, Komatsu A, Tajima T, et al (2012) Identification of chemotaxis sensory proteins for amino acids in Pseudomonas fluorescens PfO-1 and their involvement in chemotaxis to tomato root exudate and root colonization. Microbes Environ. 27:462-469.

Oliveira JS, Santos EM, Zanine AM, et al (2007) Populações microbianas e composição química de silagem de capimMombaça (Panicum maximum) inoculado com Streptococcus bovis isolado de rúmen. Arch Vet Sci7. v. 12.

Pinloche E, McEwan N, Marden JP, et al (2013) The effects of a probiotic yeast on the bacterial diversity and population structure in the rumen of cattle. PLoS One. 8:10.

Ramakrishna W, Yadav R, Li K (2019) Plant growth promoting bacteria in agriculture: Two sides of a coin. Appl Soil Ecol. 138:10-18.

Rigobelo EC, Cardozo MV, de Avila FA, Blackall PJ (2016) An evaluation of the use of probiotics and manure composting as strategies to reduce levels of shiga toxinproducing Escherichia coli in sheep. African J Microbiol Res. 10:1011-1017.

Russell JB, O'Connor JD, Fox DG, et al (1992) A net carbohydrate and protein system for evaluating cattle diets: I. Ruminal fermentation. J Anim Sci. 70:3551-3561.

Santos RM, Kandasamy S, Rigobelo EC (2018) Sugarcane growth and nutrition levels are differentially affected by the application of PGPR and cane waste. Microbiologyopen. 7.

Sarruge JR, Haag HP (1974) Análises químicas em plantas. Esalq Piracicaba

Schmidt JE, Gaudin ACM (2018) What is the agronomic potential of biofertilizers for maize? A meta-analysis. Fems Microbiol Ecol. 94:10.

Schortemeyer M, Hartwig UA, Hendrey GR, Sadowsky MJ (1996) Microbial community changes in the rhizospheres of white clover and perennial ryegrass exposed to free air carbon dioxide enrichment (FACE). Soil Biol Biochem. 28:1717-1724.

Schwyn B, Neilands JB (1987) Universal chemical assay for the detection and determination of siderophores. Anal Biochem. 160:47-56.

Shapiro SS, Wilk MB (1965) An analysis of variance test for normality (Complete samples). 
Shenker M, Oliver I, Helmann M, et al (1992) Utilization by tomatoes of iron mediated by a siderophore produced by Rhizopus-arrhizus. J Plant Nutr. 15:2173-2182.

Sureshbabu K, Amaresan N, Kumar K (2016) Amazing multiple function properties of plant growth promoting rhizobacteria in the rhizosphere soil. Int J Curr Microbiol Appl Sci. 5:661-683.

Talboys PJ, Owen DW, Healey JR, et al (2014) Auxin secretion by Bacillus amyloliquefaciens FZB42 both stimulates root exudation and limits phosphorus uptake in Triticum aestivum. BMC Plant Biol. 14:9.
Tan SY, Yang CL, Mei XL, et al (2013) The effect of organic acids from tomato root exudates on rhizosphere colonization of Bacillus amyloliquefaciens T-5. Appl Soil Ecol. 64:15-22.

Wollum A (1982) Cultural methods for soil microorganisms. In: A. L.; Miller, R. H.; Keeney Dr (ed) Methods of soil analysis. pp 781-802.

Ye J, Zhong T, Zhang D, et al (2019) The auxin-regulated protein zmauxrp1 coordinates the balance between root growth and stalk rot disease resistance in maize. Mol Plant. 12:360-373. 